\title{
Elderly Characteristics with Frailty Syndrome by Frailty Index Questionnaire - 40 (FI - 40) at Bandung Nursing Home
}

\author{
Ivany R Rahmadani*, Lazuardhi Dwipa**, Yuni S Pratiwi*** \\ *Faculty of Medicine Padjadjaran University \\ **Department of Internal Medicine \\ Faculty of Medicine Padjadjaran University-Hasan Sadikin General Hospital \\ ***Department of Anatomy, Physiology, and Biology Cell, \\ Faculty of Medicine Padjadjaran University \\ Jl. Prof. Eyckman No. 38 Bandung 40161 Indonesia \\ Email: ivanyrizkyrahmadani@gmail.com
}

\begin{abstract}
Frailty syndrome is a state of decreased body function, thereby increasing susceptibility to poor clinical outcomes. The risks of developing frailty syndrome increase in the elderly at Nursing Home. This study is expected to provide characteristic data of frailty syndrome as the basis for the prevention and management for the elderly. This study is conducted by using a descriptive quantitative design. The data is taken by using FI-40 questionnaire consisting of 40 questions in the elderly at Bandung done by using total sampling. There are 42(58.3\%) of pre-frail and 7(9.7\%) of frail elderly out of 72 data. Pre-frail prevails mostly in women (29 subjects; 69.1\%) and at age of 60-69 years in 18 subjects (42.8\%). Frail elderly is found mostly in women (3 subjects; $42.8 \%)$ and aged $70-79$ years ( 3 subjects ; (42.8). The most common cause of frailty is eye and foot problems in $7(100 \%)$. The most common cause of pre-frail is the assumption of health level in 35(83.3\%). This study concludes that frailty syndrome is common among the elderly and special attention must be paid to eye and foot problems.
\end{abstract}

Keywords: elderly, frailty syndrome, FI-40 questionnaire, nursing home 


\title{
Karakteristik Lanjut Usia dengan Sindroma Frailty berdasarkan Kuesioner Frailty Index - 40 (FI - 40) di Panti Werdha Bandung
}

\author{
Ivany R Rahmadani*, Lazuardhi Dwipa**, Yuni S Pratiwi*** \\ *Fakultas Kedokteran Universitas Padjadjaran \\ **Departemen Ilmu Penyakit Dalam \\ Fakultas Kedokteran Universitas Padjadjaran - Rumah Sakit Hasan Sadikin \\ ****Departemen Anatomi, Fisiologi dan Biologi Sel \\ Fakultas Kedokteran Universitas Padjadjaran - Rumah Sakit Hasan Sadikin \\ J1. Prof. Eyckman No. 38, Bandung, 40161 \\ Email : ivanyrizkyrahmadani@gmail.com
}

\begin{abstract}
Abstrak
Sindroma frailty merupakan suatu keadaan terjadinya penurunan fungsi tubuh sehingga meningkatkan kerentananan terhadap perburukan manifestasi klinis. Risiko terjadinya sindroma frailty meningkat pada lansia di Panti Werdha. Penelitian ini bertujuan untuk memberikan data karakteristik sindroma frailty sebagai dasar pencegahan dan tata laksana terhadap keadaan lansia. Penelitian ini dilakukan menggunakan studi desain deskriptif kuantitatif. Data diambil secara potong lintang menggunakan kuesioner FI-40 yang terdiri dari 40 pertanyaan pada lansia di Panti Werdha Bandung menggunakan metode total sampling. Terdapat $42(58,3 \%)$ lansia prefrail dan $7(9,7 \%)$ lansia frailty dari 72 data. Lansia dengan kondisi pre-frail terbanyak adalah wanita yaitu 29 orang $(69,1 \%)$ dan berusia $60-69$ tahun yaitu 18 orang $(42,8 \%)$. Lansia dengan kondisi frailty terbanyak adalah wanita yaitu 3 orang $(42,8 \%)$ dan berusia $70-79$ tahun 3 $(42,8 \%)$. Karakteristik penyebab frailty terbanyak adalah masalah mata dan kaki sejumlah 7 $(100 \%)$. Karakteristik penyebab pre-frail terbanyak adalah anggapan mengenai tingkat kesehatan sendiri sejumlah 35 (83,3\%). Karakteristik lansia pre-frail dan frailty di Panti Werdha Bandung terdiri dari jenis kelamin lebih banyak perempuan dengan rata-rata usia 60-69 tahun pada pre-frail dan 70-79 tahun pada frailty. Anggapan mengenai tingkat kesehatan sendiri merupakan karakteristik terbanyak pada pre - frail. Masalah pada mata dan kaki merupakan karakteristik terbanyak pada sindroma frailty.
\end{abstract}

Kata Kunci: lanjut usia, sindroma frailty, kuesioner FI-40, panti werdha. 


\section{Research Article}

\section{Pendahuluan}

Indonesia merupakan negara yang memiliki banyak penduduk lanjut usia. ${ }^{1}$ Menjadi tua merupakan suatu proses yang mengubah seorang dewasa sehat menjadi seorang yang frail. $^{2}$ Frailty sudah berkembang sekitar 7\% - 16,3\% pada individu berusia 65 tahun atau lebih dan menyebabkan seseorang cenderung jatuh, memerlukan rawat inap, menurunnya status fungsional dan kematian. ${ }^{3}$ Luaran klinis yang buruk tersebut dapat dicegah dengan cara dilakukannya penapisan yang secara umum dibagi menjadi dua, yaitu berdasarkan fenotip dan akumulasi defisit. ${ }^{4}$ Adapun kuesioner yang dipakai di Indonesia untuk skrining Sindroma Frailty berdasarkan akumulasi defisit atau gangguan, yaitu FI $-40{ }^{5}$

Sebuah penelitian menunjukkan bahwa kualitas hidup yang lebih baik didapatkan pada lansia yang tinggal bersama keluarga atau komunitas dibandingkan dengan lansia yang tinggal di panti werdha. ${ }^{6}$ Sesuai dengan adanya peningkatan Usia Harapan Hidup (UHH) di Indonesia dari 68,6 tahun menjadi 70,8 tahun sejak tahun 2004 - 2015 dan proyeksi tahun 2030-2035 mencapai 72,2 tahun $^{7}$ serta terdapat beberapa luaran negatif berupa peningkatan morbiditas, mortalitas akibat penurunan kualitas hidup serta kualitas perawatan panti werdha yang kurang baik. ${ }^{8,9}$ Penelitian ini bertujuan untuk deteksi dini sindroma frailty dengan menggunakan kuesioner FI-40 di Panti Werdha Bandung. Penelitian ini diharapkan dapat memberikan data karakteristik sindroma frailty dan membantu meningkatkan kualitas hidup lansia di Panti Werdha Bandung sebagai data dasar yang menunjang prioritas tatalaksana perawatan lansia di panti werdha. Adapun, pada penelitian ini dipilih lokasi Balai Perlindungan Sosial Tresna Werdha Ciparay dan Panti Werdha Budi Pertiwi, karena panti werdha tersebut merupakan milik pemerintah provinsi Jawa Barat dan dinas sosial, sehingga diharapkan penelitian ini dapat mewakili data untuk provinsi Jawa Barat.

\section{Metode}

Penelitian dilakukan antara bulan Februari - Juni 2017 di Panti Werdha Bandung, yaitu Balai Perlindungan Sosial Tresna Werdha Ciparay dan Panti Werdha Budi Pertiwi menggunakan studi desain deskriptif kuantitatif. Subjek penelitian adalah lansia yang berada di Panti Werdha pada bulan Februari - Juni 2017 yang memenuhi kriteria penelitian dan telah mendapat izin dari pihak Panti Werdha dengan kriteria inklusi yaitu berumur > 60 tahun, kooperatif dan bersedia ikut dalam penelitian dengan menandatangani informed consent, sedangkan kriteria eksklusi adalah mengalami gangguan kognitif berat dan mengalami imobilisasi fisik. Jumlah sampel yang digunakan pada penelitian ini sebanyak 74 orang, menggunakan teknik total sampling. 


\section{Research Article}

Data diambil secara primer dengan terlebih dahulu membuat surat pengajuan etik dan surat izin penelitian. Prosedur penelitian diawali dengan mewawancarai lansia yang tinggal di panti werdha, menanyakan kesediaan mereka untuk ikut. Sejumlah 80 orang lansia diberikan informed consent, selanjutnya dilakukan pemeriksaan kognitif dengan menggunakan kuesioner MMSE. Setelah itu ditentukan gangguan kognitifnya apakah normal, sedang, ringan, maupun berat; dan dilakukan penentuan kriteria inklusi dan eksklusi.. Lansia dengan gangguan kognitif berat dan mengalami imobilisasi fisik akan dieksklusi. Jika memenuhi kriteria maka dilakukan keseluruhan wawancara menggunakan kuesioner. Terdapat 72 lansia yang memenuhi kriteria untuk menjadi subjek penelitian dari total 80 lansia di Panti Werdha. Variabel yang dilakukan untuk menilai frailty pada penelitian ini adalah usia, jenis kelamin, gangguan penglihatan, gangguan pendengaran, bantuan untuk makan, bantuan untuk berpakaian dan melepas pakaian, kemampuan untuk merawat diri, bantuan untuk berjalan, bantuan untuk tidur dan bangun tidur, bantuan untuk mandi, bantuan untuk pergi ke kamar mandi, bantuan untuk menelepon, bantuan untuk berjalan mencapai tempat-tempat kegiatan, bantuan untuk berbelaja, bantuan untuk mempersiapkan makanan sendiri, bantuan untuk pekerjaan rumah tangga, kemampuan untuk minum obat, kemampuan untuk mengurus keuangan sendiri, anggapan mengenai tingkat kesehatan sendiri, kesulitan untuk melakukan aktivitas sehari-hari, hidup sendiri, batuk, merasa lelah, hidung tersumbat atau bersin, tekanan darah tinggi, masalah jantung dan peredaran darah, stroke atau akibat stroke, artritis atau rematik, penyakit parkinson, masalah mata, masalah telinga, masalah gigi, masalah paru, masalah lambung, masalah ginjal, tidak dapat mengontrol kemih, tidak dapat mengontrol buang air besar, diabetes, masalah dengan kaki atau pergelangan kaki, masalah dengan saraf, masalah kulit, fraktur.

Analisis data dilakukan dengan menentukan skor dan kategori sesuai dengan kuesioner $\mathrm{FI}-40$.

\section{Hasil}

Jumlah sampel yang didapatkan pada penelitian ini adalah sebesar 72 sampel dengan rincian normal sebanyak 23, pre-frail sebanyak 42 kasus dan sindroma frailty sebanyak 7 kasus. Tabel 1 menunjukkan karakteristik lansia di Panti Werdha bersadarkan usia, jenis kelamin, dan klasifikasi sindroma frailty. Pada tabel tersebut didapatkan bahwa lansia pre-frail dan frailty lebih banyak wanita yaitu $69,1 \%$ dan $71,4 \%$. 
Tabel 1 Karakteristik Lansia

\begin{tabular}{llccc}
\hline No & Karakteristik & $\begin{array}{c}\text { Normal } \\
\mathbf{n}(\boldsymbol{\%})\end{array}$ & $\begin{array}{c}\text { Pre-Frail } \\
\mathbf{n}(\boldsymbol{\%})\end{array}$ & $\begin{array}{c}\text { Frailty } \\
\mathbf{n}(\boldsymbol{\%})\end{array}$ \\
\hline 1. & Usia & & & \\
& $-\quad 60-69$ tahun & $7(30,4)$ & $18(42,8)$ & $2(28,5)$ \\
& $-\quad 70-79$ tahun & $8(34,7)$ & $12(28,5)$ & $3(42,8)$ \\
& $-\quad \geq 80$ tahun & $8(34,7)$ & $12(28,5)$ & $2(28,5)$ \\
\hline 2. & Jenis Kelamin & & & \\
& $-\quad$ Laki-laki & $8(34,7)$ & $13(30,9)$ & $2(28,5)$ \\
& $-\quad$ Perempuan & $15(65,3)$ & $29(69,1)$ & $5(71,4)$ \\
\hline 3. & Penggolongan Frailty & $23(31,9)$ & $42(58,3)$ & $7(9,7)$ \\
\hline
\end{tabular}

Rata - rata lansia dengan pre-frail berusia 60-69 tahun dengan jenis kelamin wanita, dan rata-rata lansia dengan frailty berusa 70-79 tahun dengan jenis kelamin wanita.

Tabel 2 Daftar Pertanyaan FI-40 dan Jawaban Responden Terbanyak

\begin{tabular}{|c|c|c|c|c|}
\hline No & Karakteristik & $\begin{array}{c}\text { Normal } \\
(\%)\end{array}$ & $\begin{array}{l}\text { Pre-Frail } \\
(\%)\end{array}$ & $\begin{array}{c}\text { Frailty } \\
(\%)\end{array}$ \\
\hline 1 & Gangguan penglihatan & & & 99,8 \\
\hline 2 & Gangguan pendengaran & & 47,5 & \\
\hline 3 & Bantuan untuk makan & & & \\
\hline 4 & $\begin{array}{l}\text { Bantuan untuk berpakaian dan melepas } \\
\text { pakaian }\end{array}$ & & & \\
\hline 5 & Kemampuan untuk merawat diri & & & \\
\hline 6 & Bantuan untuk berjalan & & & 57,1 \\
\hline 7 & Bantuan untuk tidur dan bangun tidur & & & \\
\hline 8 & Bantuan untuk mandi & & & \\
\hline 9 & Bantuan untuk pergi ke kamar mandi & & & \\
\hline 10 & Bantuan untuk menelepon & & 38,1 & \\
\hline 11 & $\begin{array}{l}\text { Bantuan untuk berjalan mencapai tempat- } \\
\text { tempat kegiatan }\end{array}$ & & & 42,8 \\
\hline 12 & Bantuan untuk berbelanja & & & $\mathbf{7 1 , 4}$ \\
\hline 13 & $\begin{array}{l}\text { Bantuan untuk mempersiapkan makanan } \\
\text { sendiri }\end{array}$ & & & 57,1 \\
\hline 14 & Bantuan untuk pekerjaan rumah tangga & & & 85,7 \\
\hline 15 & Kemampuan untuk minum obat & & & \\
\hline 16 & $\begin{array}{l}\text { Kemampuan untuk mengurus keuangan } \\
\text { sendiri }\end{array}$ & & & 57,1 \\
\hline 17 & $\begin{array}{l}\text { Anggapan baik mengenai tingkat kesehatan } \\
\text { sendiri }\end{array}$ & & 59,5 & \\
\hline 18 & $\begin{array}{l}\text { Kesulitan untuk melakukan aktivitas sehari- } \\
\text { hari }\end{array}$ & & & 57,1 \\
\hline 19 & Hidup sendiri & & & 57,1 \\
\hline 20 & Batuk & & & \\
\hline 21 & Merasa lelah & & & $\mathbf{7 1 , 4}$ \\
\hline 22 & Hidung tersumbat atau bersin & & & 28,5 \\
\hline 23 & Tekanan darah tinggi & & 54,8 & 85,7 \\
\hline 24 & Masalah jantung dan peredaran darah & & & \\
\hline 25 & Stroke atau akibat stroke & & & \\
\hline 26 & Artritis atau rematik & & & 85,7 \\
\hline
\end{tabular}


Penyakit Parkinson

28 Masalah mata

Masalah telinga

Masalah gigi

Masalah paru-paru

Masalah ginjal

Tidak dapat mengontrol kemih

Tidak dapat mengontrol BAB

Diabetes

Masalah kaki atau pergelangan kaki

40 Fraktur

Tabel 2 menunjukkan karakteristik lansia dengan sindroma frailty di Panti Werdha Bandung berdasarkan kuesioner FI - 40. Pada tabel tersebut didapatkan bahwa lansia pre-frail lebih banyak dengan karakteristik anggapan baik mengenai tingkat kesehatan sendiri $(59,5 \%)$, sedangkan lansia dengan sindroma frailty lebih banyak dengan karakteristik masalah mata serta masalah kaki dan pergelangan kaki (100\%).

\section{Diskusi}

Hasil penelitian ini menunjukkan bahwa lansia dengan pre - frail sebanyak 58,3\% dan sindroma frailty 9,7\%. Hasil ini sesuai dengan penelitian Brigitte yang menyebutkan bahwa kondisi pre - frail lebih banyak dibandingkan frailty. ${ }^{10}$ Sebagian besar lansia pre - frail dan frailty adalah wanita dengan presentase $69,1 \%$ dan $71,4 \%$. Hasil ini sesuai dengan penelitian Qian-Li Xue yang juga menyebutkan bahwa wanita cenderung lebih rentan dibandingkan dengan lelaki. ${ }^{11}$ Semakin tinggi usia semakin tinggi pula prevalensi sindroma frailty, ${ }^{12}$ namun pada penelitian ini didapatkan bahwa prevalensi pre - frail dan sindroma frailty lebih tinggi pada usia 60 - 79 tahun dibandingkan dengan $\geq 80$ tahun. Hal ini dijelaskan oleh fakta bahwa tingkat mortalitas pada usia $\geq 80$ tahun lebih tinggi dibandingkan dengan $60-79$ tahun. $^{13}$

Karakteristik pre - frail dengan prevalensi terbanyak berdasarkan kuesioner FI - 40 adalah anggapan baik mengenai tingkat kesehatan sendiri (59,5\%), tekanan darah tinggi $(54,8 \%)$ dan masalah mata $(54,8 \%)$. Hal ini disebabkan karena pada usia pertengahan, lensa mata menjadi kurang fleksibel dan berkurangnya kemampuan untuk memfokuskan objek. ${ }^{14}$ Tekanan darah menunjukkan angka yang tinggi karena seiring bertambahnya usia, lemak visceral dan leptin juga akan meningkat yang akan menyebabkan tingginya risiko menderita tekanan darah tinggi. 


\section{Research Article}

Karakteristik sindroma frailty dengan prevalensi tertinggi adalah masalah mata dan masalah kaki serta pergelangan kaki (100\%), bantuan minimal untuk pekerjaan rumah tangga, tekanan darah tinggi, dan artritis atau rematik (85,7\%), bantuan minimal untuk berbelanja, merasa lelah, dan masalah gigi $(71,4 \%)$. Hal ini disebabkan terjadinya beberapa perubahan dengan pertambahan usia, seperti terjadinya kerusakan sel - sel pada tubuh akan meningkatkan risiko untuk terjadinya inflamasi kronis yang akan menyebabkan penyakit rematik pada lansia, berkurangnya bantalan lemak yang melindungi bagian bawah kaki dan jika terdapat kelebihan berat badan maka bagian tulang dan ligamen pada bagian kaki akan memikul beban yang lebih besar dari normal. ${ }^{15}$

Hasil penelitian ini sesuai dengan penelitian Euphemia Seto, dkk yang menyebutkan bahwa karakteristik yang paling banyak didapatkan pada lansia sesuai dengan kuesioner FI - 40 adalah anggapan mengenai tingkat kesehatan sendiri, masalah pada mata. Karakteristik yang jarang yaitu adalah ketergantungan, yang mencakup bantuan untuk berpakaian dan melepas pakaian, bantuan untuk makan, bantuan untuk mandi. Hal ini disebabkan karena sebagian besar lansia masih dapat mempertahankan kemandiriannya. ${ }^{16}$

Keterbatasan penelitian ini diantaranya adalah penyakit tidak bisa dikonfirmasi dengan benar. Hal tersebut dikarenakan metode yang dilakukan dalam penelitian ini hanya anamnesis.

\section{Simpulan}

Dari penelitian ini didapatkan bahwa prevalensi pre - frail dan sindroma frailty pada lansia di Panti Werdha Budi Pertiwi dan Balai Perlindungan Sosial Tresna Werdha Ciparay adalah 56,7\% dan 9,4\% dengan gambaran; jenis kelamin perempuan lebih banyak $(69,1 \%$ dan $71,4 \%)$ dengan rata - rata usia 60 - 69 tahun dan 70 - 79 tahun (28,5\% dan 42,8\%). Anggapan mengenai tingkat kesehatan sendiri merupakan karakteristik terbanyak pada pre - frail. Masalah pada mata dan kaki merupakan karakteristik terbanyak pada sindroma frailty.

Saran untuk penelitian ini adalah sebaiknya penelitian ini dilakukan di wilayah lain, seperti Panti Werdha Jawa Barat. Saran terhadap Panti Werdha agar memberikan pelayan terhadap lansia sesuai dengan keadaan lansia tersebut.

\section{Daftar Pustaka}

1. Peraturan Menteri Kesehatan Republik Indonesia Nomor 25 Tahun 2016 tentang Rencana Aksi Nasional Kesehatan Lanjut Usia Tahun 2016-2019.

2. Setiati S, Kuntjoro H, Arya GR. Proses menua dan implikasi klinik. In: Suyono S, editor. Buku Ajar Ilmu Penyakit Dalam. Ketiga. Jakarta: Balai Penerbit FKUI; 2006. p. 1335.

3. Grice Robinson S, Bushinski S. Managing frailty syndrome. Today's Geriatr Med. 2015. 8:30.

4. Cesari M, Gambassi G, Abellan KG, Vellas B. The frailty phenotype and the frailty index: different instruments for different purposes. Age Ageing. 2014; 43(1): 10-2. Available from:http://dx.doi.org/10.1093/ageing/aft160. 


\section{Research Article}

5. Buckinx F, Rolland Y, Reginster J-Y, Ricour C, Petermans J, Bruyère O. Burden of frailty in the elderly population: perspectives for a public health challenge. Arch Public Heal. 2015; 73(1): 19. Available from: http://www.ncbi.nlm.nih.gov/pmc/articles/PMC4392630/.

6. Putri ST, Fitriana LA, Ningrum A, Sulastri A. Studi komparatif: kualitas hidup lansia yang tinggal bersama keluarga dan panti. Jurnal Pendidikan Keperawatan Indonesia. 2014; 229: 1-6.

7. Kementerian Kesehatan, R.I. Situasi lanjut usia (lansia). Pusat Data dan Informasi Kementerian Kesehatan RI. 2016

8. Paredes MSA, Almeida NJ, Silva LM, Tura RLF, et al. Health problems of institutionalized elderly. Int Arch Med. 2016; 1-7. Available from: http://imed.pub/ojs/index.php/iam/article/view/1468.

9. Luppa M, Luck T, Weyerer S, König H-H, Brähler E, Riedel-Heller SG. Prediction of institutionalization in the elderly. A systematic review. Age Ageing. 2009; 39(1): 31-8.

10. Santos-Eggimann B, Cuénoud P, Spagnoli J, Junod J. Prevalence of frailty in middle-aged and older communitydwelling Europeans living in 10 countries. J Gerontol Ser A Biol Sci Med Sci. 2009; 64A(6): 675-81. Available from: http://www.ncbi.nlm.nih.gov/pmc/articles/PMC2800805/.

11. Xue Q-L. The frailty syndrome: definition and natural history. Clin Geriatr Med. 2011; 27(1): 1-15. Available from: http://www.ncbi.nlm.nih.gov/pmc/articles/PMC3028599/.

12. Fedarko NS. The biology of aging and frailty. Clin Geriatr Med. 2011; 27(1): 27-37. Available from: http://www.ncbi.nlm.nih.gov/pmc/articles/PMC3052959/.

13. Foley DJ, Heimovitz HK, Guralnik JM, Brock DB. Driving life expectancy of persons aged 70 years and older in the United States. Am J Public Health. 2002; 92(8): 1284-9. Available from: http://www.ncbi.nlm.nih.gov/pmc/articles/PMC1447231/.

14. Lechtzin N. Effects of aging on the respiratory system - lung and airway disorders - Merck manuals consumer version. Merck manual. Available from: http://www.merckmanuals.com/home/lung-and-airwaydisorders/biology-of-the-lungs-and-airways/effects-of-aging-on-the-respiratory-system. 2015.

15. Sun Z. Aging, arterial Stiffness, and hypertension. Hypertension. 2015; 65(2): 252 LP-6. Available from: http://hyper.ahajournals.org/content/65/2/252.abstract.

16. Seto E, Setiati S, Laksmi PW, Tamin TZ. Diagnostic test of a scoring system for frailty syndrome in the elderly according to cardiovascular health study of osteoporotic fracture and comprehensive geriatric assessment based Frailty Index Compared with Frailty Index 40 Items. Acta Med Indones. 2015; 47(3): 183-7. 